\title{
Probing Trapped Ion Energies Via Ion-Molecule Reaction Kinetics: Quadrupole Ion Trap Mass Spectrometry
}

\author{
Cecilia Basic, John R. Eyler, and Richard A. Yost \\ Department of Chemistry, University of Florida, Gainesville, Florida, USA
}

\begin{abstract}
We present a detailed study of the energies of the ions stored in a quadrupole ion trap mass spectrometer (QITMS). Previous studies have shown that the rate constant, $k$, for the charge exchange reaction $\mathrm{Ar}^{+}+\mathrm{N}_{2} \rightarrow \mathrm{N}_{2}^{+}+\mathrm{Ar}$ increases with increasing ion-molecule center-ofmass kinetic energy (K.E. ${ }_{\mathrm{cm}}$ ). Thus, we have determined $k$ for this chemical "thermometer" reaction at a variety of $\mathrm{Ar}$ and $\mathrm{N}_{2}$ pressures and have assigned $K . E_{. \mathrm{cm}}$ values as a function of the $\mathrm{q}$, of the $\mathrm{Ar}^{+}$ion both with and without $\mathrm{He}$ buffer gas present in the trap. The K.E. ${ }_{\mathrm{cm}}$ energies are found to lie within the range $0.11-0.34 \mathrm{eV}$ over the variety of experimental conditions investigated. Quantitative "cooling" effects due to the presence of He buffer gas are reported, as are increases in K.E. cm $_{\text {due }}$ to an increase in the $q_{2}$ of the $\mathrm{Ar}^{+}$ion. "Effective" temperatures of the $\mathrm{Ar}^{+}$ions in He buffer are determined based on a MaxwellBoltzmann distribution of ion energies. The resulting temperatures are found to lie within the range $\approx 1700-3300 \mathrm{~K}$. We have also examined the K.E.crn values arising from the chemical thermometer reaction of $\mathrm{O}_{2}^{+}$with $\mathrm{CH}_{4}$, as previous assignments of effective ion temperatures based on this reaction have been called into question. ( $]$ Am Soc Mass Spectrom $1992,3,776-726)$
\end{abstract}

$I$ $n$ recent years the quadrupole ion trap mass spectrometer (OTTMS) has seen increased use in both routine and more advanced methods of tandem mass spectrometric analyses. The ability to sequentially mass-select and store reagent ions of a single mass-to-charge ratio allows MSn analyses [1-4] as well as selected-reagent ion chemical ionization (CI) [5]. The QITMS has also becn used in the study of ion molecule reaction kinetics $[6-10]$, in proton affinity [11-14] and relative gas-phase basicity determinations [15], and in recent ion structural studies [16, 17]. As the ion trap becomes increasingly popular in both fundamental and applied mass spectrometric studies, knowledge of the average ion energies under a variety of experimental conditions becomes increasingly important.

The energy of the ions stored in a QTTMS is a function of both the heating effects induced by the radiofrequency ( $\mathrm{rf}$ ) field and the cooling effects due to collisions with background gases. Theoretical estimations of the ion kinetic energies have been performed by using a variety of numerical methods including a pseudopotential well model of the ion motion [18, 19], a "smoothed general solution" of the first derivative of

Mddress reprint requests to Richard $A$. Yost, Department of Chemistry, University of Florida, Gainesville, FL 32611-2046. the Mathieu equation $[20,21]$, and a phase-space dynamical model of the ion cloud $[22,23]$. These models, which may or may not incorporate collisional processes, result in average kinetic energies in the range 0.1-30 eV for the $\mathrm{Ar}^{+}$ions, with maximum ion kinetic energies as high as $50 \mathrm{eV}$, based on the $\mathrm{q}_{\mathrm{z}}$ of the ion, where the $q_{z}$ value is directly proportional to the amplitude of the of drive potential applied to the ring These models have been summarized in detail elsewhere $[24,25]$. André and Vedel et al. [26-30] have presented a three-dimensional model of the ion cloud based on the temporal invariance of the statistical properties of the ions. According to this model, if space charge effects are ignored, collisions with the buffer gas give rise to an equilibrium repartition of the spatial and velocity components of the ion cloud in the form of a Gaussian distribution. This allows calculation of a "pseudotemperature" to describe the ion cloud. Typical calculated pseudotemperatures for $\mathrm{Cs}^{\dagger}$ ions in $10^{-4}$ tor of He buffer at $300 \mathrm{~K}$ vary from $500-5000 \mathrm{~K}$ based on the working point of the ion on the stability diagram [27]. This model has been extended to incorporate space charge effects [28, 29].

A number of expcrimental determinations of the average energies of trapped monoatomic species have also been reported. Bolometric methods [31, 32], optical measures [33-39], and a time-of-flight method for profiling the extracted ion cloud [40] have been used to 
probe ion energies in the absence and presence of $\mathrm{He}$ buffer gas. In the absence of He buffer, the ion energies were found to be approximately $10 \%$ of the pseudopotential well depth, $e \mathrm{D}(\mathrm{eV})[31,33-35]$, although a lower average energy equal to $2 \% e \mathrm{D}$ was also reported [39]. Ion energies measured in the presence of He buffer vary from $10 \% \mathrm{eD}$ [38] to energies between $0.2 \%$ and $5 \% e \mathrm{D}[35,36,40]$. The results of these ion energy measurements have also been summarized in ref 30 .

To date, the experimental determination of the energies of the stored ions by using chemical "thermometer" reactions has been limited. Early reports by Lawson et al. [7] estimate the average ion energy to be on the order of 1-3 eV with no $\mathrm{He}$ buffer gas. These energies were based on the relative abundances and known appearance potentials of the $m / z 15\left(\mathrm{CH}_{3}^{+}\right)$and $m / z 27\left(\mathrm{C}_{2} \mathrm{H}_{3}^{+}\right)$ions from ionized methane and on the appearance of the $m / z 16\left(\mathrm{NH}_{2}^{+}\right)$and $m / z 18\left(\mathrm{NH}_{4}^{+}\right)$ ions from ionized ammonia. An "effective" ion temperature of $335 \mathrm{~K}$ has been reported as the internal energy for a series of substituted proton-bound pyridine dimer ions in a QITMS following collisional activation [15]. Nourse and Kenttämaa [10] report effective ion temperatures of between $600 \mathrm{~K}$ and $700 \mathrm{~K}$ for $\mathrm{O}_{2}^{\prime}$ in He buffer gas prior to resonant excitation, and a temperature of approximately $1300 \mathrm{~K}$ for $\mathrm{O}_{2}^{+}$following excitation. These effective temperatures of the $\mathrm{O}_{2}^{+}$ ions are based on the rate constant, $k$, and the branching ratio of the endothermic product ions arising from the reaction of $\mathrm{O}_{2}^{+}$with $\mathrm{CH}_{4}[41,42]$.

We have carried out a detailed kinetic study to probe the average energies of ions stored in a QITMS prior to resonant excitation. Our approach is similar to that of Nourse and Kenttämaa [10]; however, we have determined the rate constant, $k$, for the well-known charge exchange reaction $[43-47]$,

$$
\mathrm{Ar}^{+}+\mathrm{N}_{2} \stackrel{k}{\rightarrow} \mathrm{N}_{2}^{+}+\mathrm{Ar}
$$

Previous flow drift studies have shown that $k$ for reaction 1 increases with increasing ion-molecule center-of-mass kinetic energy (K.E. ${ }_{\mathrm{cm}}$ ) [43-45]. Thus, this reaction can be used as a chemical thermometer to estimate the K.E. $\mathrm{cm}$ of reaction 1 under a given set of experimental conditions in the QITMS [48]. We have determined $k$ for reaction 1 and assigned $K . E_{. c m}$ values at a variety of $\mathrm{Ar}$ and $\mathrm{N}_{2}$ neutral gas pressures and pressure ratios, as a function of He buffer gas pressure, and $\mathrm{q}_{\mathbf{z}}\left(\mathrm{Ar}^{+}\right)$values.

We have also reexamined the reaction of $\mathrm{O}_{2}^{+}$with $\mathrm{CH}_{4}$ in the QTTMS. A recent study by Viggiano et al. [49] concluded that the original variable temperature clata reported in [41] and utilized by Nourse and Kenttämaa to assign effective ion temperatures is in error at low temperatures. They further concluded that the relation $\Delta K ._{.}{ }_{\mathrm{cm}}$ equals $n k T_{\text {eff }}$ developed in ref 41 , where $\Delta K . E_{c \mathrm{~cm}}$ is equal to the added kinetic energy of the drift tube, is incorrect. Thus, the ion temperatures arising from the $k$ versus $\mathrm{T}_{\text {eff }}$ curve reported in ref 41 have been called into question.

Chemical thermometer probes using the reaction of $\mathrm{Ar}^{+}$with $\mathrm{N}_{2}$ have been performed on a Fourier transform ion cyclotron resonance mass spectrometer by Bruce and Eyler [50] and are presented in a companion paper in this issue.

\section{Experimental}

\section{Instrumental}

All experiments were performed on a Finnigan MAT (San Jose, CA) quadrupole ion trap mass spectrometer (ITMS) with an rf drive frequency of $1.1 \mathrm{MHz}$, and a ring electrode radius, $r_{0}$ of $1 \mathrm{~cm}$. Reagent and He buffer gases were introduced into the ion trap chamber via Granville-Phillips (Boulder, $\mathrm{CO}$ ) variable leak valves. The He buffer gas line was cryocooled to remove excess water. The ion trap manifold temperature was $100^{\circ} \mathrm{C}$.

The reaction rate constants were determined by performing an $\mathrm{rf} / \mathrm{dc}$ isolation of the reactant ion of interest by using the upper apex of the stability diagram (apex isolation) and then allowing the ions to react for a variable reaction time, $t$. A schematic of the scan function employed is presented in Figure 1. The reagent ions were formed by electron ionization (EI) within the volume of the ion trap. In the ITMS, the ionizing electron energy is a function of both the amplitude of the $\mathrm{rf}$ voltage applied to the ring during ionization and the phase of the rf as the electron enters the trap. As such, no single electron energy can be assigned. However, simulations of the electron energy have shown that for an rf amplitude of $112 \mathrm{~V}_{0-p}$ (lowmass cut-off $=10 \mathrm{u}$ ), the average electron energy varies from 6-55 eV over one cycle of the rf [51]. The ionization time was varied to minimize space charge as witnessed in distortions of the peak from a Gaussian profile in full-scan mode. Typical ionization times var-

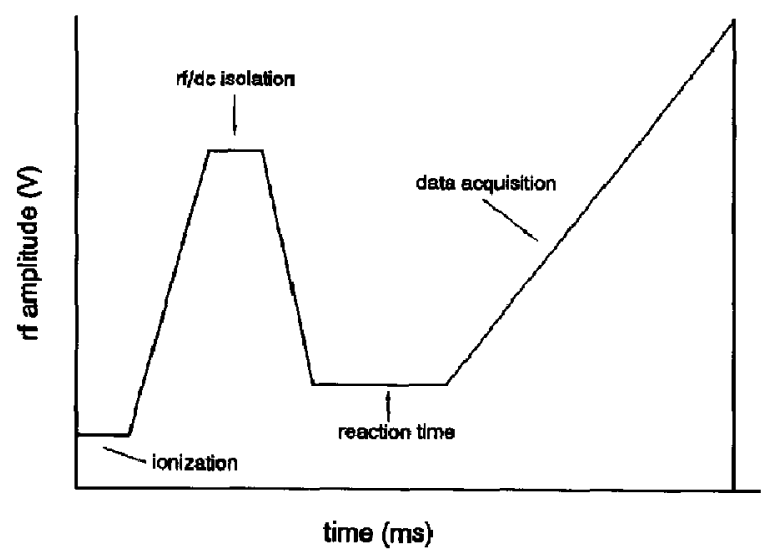

Figure 1. Schematic scan function (not to scale) for performing ion-molecule reactions rate studies on a QITMS. 
ied from 0.5 to $1 \mathrm{~ms}$ with no He buffer gas, and 0.05 to $0.5 \mathrm{~ms}$ with He buffer gas.

Reactant ions of a single mass-to-charge ratio were isolated by first ramping the amplitude of the ring $\mathrm{rf}$ voltage so that the ions of interest defined a $q_{z} \approx 0.75$ located under the upper apex of the stability diagram and then applying a negative $\mathrm{dc}$ pulse to the ring electrode for $0.30 \mathrm{~ms}$. The optimum de amplitude was approximately equal to the mass of the reactant ion of interest, that is, $-38 \mathrm{~V}$ for $\mathrm{Ar}^{1}$ and $-30 \mathrm{~V}$ for $\mathrm{O}_{2}^{+}$. Following isolation, the ring $\mathrm{rf}$ amplitude was ramped to a chosen $V_{0}$ value so that the reactant ion defined the specific $q_{z}$ of interest in the reaction rate determination. No ion "cooling" times were employed for the isolated $\mathrm{Ar}^{+}$ions prior to reaction with $\mathrm{N}_{2}$. Rate constants for the reaction of $\mathrm{O}_{2}^{+}$with $\mathrm{CH}_{4}$ were determined with a $200 \mathrm{~ms}$ "cooling" time to quench the excited states of the $\mathrm{O}_{2}^{+}$ions prior to apex isolation of the $\mathrm{O}_{2}^{+}$ions. A similar cooling time was reported in ref 10 .

The reaction time was varied using a FORTH program written with the FORTH programming option available with the ITMS software. A supplemental if voltage at the resonant frequency of $\mathrm{N}_{2}^{+}$(as calculated by the ITMS software) was applied to the end cap electrodes during the reaction time. In so doing, the $\mathrm{N}_{2}^{+}$product ions were ejected from the trap, thus preventing the reverse charge exchange reaction $[43,44]$. At high supplemental $\mathrm{rf}$ amplitudes ( $3 \mathrm{~V}_{0-\mathrm{p}}$ ) and long reaction times $(100 \mathrm{~ms})$ the $\mathrm{Ar}^{+}$ions could also be brought into resonance at the optimum frequency for $\mathrm{N}_{2}^{+}$ejection. Thus, to avoid possible excitation of the $\mathrm{Ar}^{+}$ions, a relatively low $1.5 \mathrm{~V}_{\mathrm{v}-\mathrm{p}}$ amplitude was chosen to eject the $\mathrm{N}_{2}^{+}$ions. Experiments in our laboratory have shown that upon application of the supplemental $\mathrm{r}$ f voltage the $\mathrm{N}_{2}^{+}$ions are ejected in less than $100 \mu s$; thus, translational driving of the reverse reaction due to the ejection of the $\mathrm{N}_{2}^{+}$ions can be neglected. No supplemental rf voltages were employed in the study of $\mathrm{O}_{2}^{+}$with $\mathrm{CH}_{4}$.

The reaction products were detected by performing a mass-selected instability scan [52] with no axial modulation applied during the acquisition ramp. The ion intensities were extracted using CHROLIST, a data reduction program developed in our laboratory, and plotted with a commercial graphing program (GRAPHER, Golden Software, Inc., Golden, CO).

All gases were obtained from Alphagaz (LaPorte, TX) and were of greater than $99.9 \%$ purity except the $\mathrm{O}_{2}$, which was of $99.5 \%$ purity.

\section{Neutral Gas Pressure Determinations}

The rate constants, $k$, were determined from the pseudo-first-order rate equation [53],

$$
\left[\mathrm{A}^{+}\right]_{\mathrm{t}}=\left[\mathrm{A}^{+}\right]_{0} \mathrm{e}^{-k|B| t}
$$

where $\left[A^{+}\right]$is the reactant ion intensity (counts), $[B]$ is the pressure of the neutral gas species (molecules $\left.\mathrm{cm}^{-3}\right), \mathrm{t}$ is the ion-molecule reaction time (s), and $k$ is the rate constant $\left(\mathrm{cm}^{3} \mathrm{~s}^{-1}\right)$. The neutral gas pressures were measured with a Bayard-Alpert type ionization gauge mounted on the ion trap chamber. Ion gauge sensitivity factors for methane and nitrogen were determined by calibrating the ion gauge controller (Granville-Phillips, Boulder, $\mathrm{CO}$, series 280 digital controller) with a capacitance manometer (MKS model $390 \mathrm{HA}-00001 \mathrm{SP} 05$, Andover, MA) over the ion gauge pressure range $1 \times 10^{-6}-1 \times 10^{-4}$ torr. This was accomplished by fitting the sensing head of the capacitance manometer to the end of a hollow solids probe. The sensor was introduced into the vacuum chamber through the solids probe inlet, allowing pressure measurements $\approx 1^{\prime \prime}$ from the ion trap. The ion gauge sensitivity factors were then calculated from the slopes of the capacitance manometer versus the ion gauge reading curves. Each calibration was performed three times. A sensitivity factor of $0.80 \pm 0.06$ was found for methane over the pressure range $4.0 \times 10^{-6}-1.1 \times$ $10^{-4}$ torr, and $1.14 \pm 0.02$ was found for nitrogen over the pressure range $2.4 \times 10^{-6}-1.1 \times 10^{-4}$ torr. The ion gauge readings were corrected with the appropriate sensitivity factor prior to the calculation of the rate constants. Note that while corrected ion gauge readings were used in the rate constant calculations, uncorrected ion gauge readings will be presented throughout this article.

\section{Calibration Reaction}

The reaction

$$
\mathrm{CH}_{4}^{+}+\mathrm{CH}_{4} \stackrel{k}{\rightarrow} \mathrm{CH}_{5}^{+}+\mathrm{CH}_{3}
$$

was used as a "calibration" reaction for the method of $k$ determinations employed in this study. The rate constant for reaction 2 is independent of ion energy $\left(k_{\text {lit }}=1.1 \times 10^{9} \mathrm{~cm}^{3} \mathrm{~s}^{-1}\right.$ [54]); thus, signiticant deviations of the experimentally determined $k$ from $k_{l i t}$ would indicate an error in the neutral gas readings due to a pressure differential between the ion trap and the ion gauge. The rate constant for the calibration reaction was calculated from the first-order exponential decay of the normalized $m / z 16$ ion signal as a function of time. The $m / z 16$ ion signal was normalized with respect to the principal ions formed: $m / z 15$, 16, 17, 19, and 29 (no $m / z 27$ or $m / z 41$ ions were seen). The decay of the $m / z 16$ was chosen as opposed to the growth of the $m / z$ ion as $\mathrm{CH}_{5}^{+}$ions react with background water at a greater rate $(k=3.7 \times$ $\left.10^{-9} \mathrm{~cm}^{3} \mathrm{~s}^{-1}\right)$ than the $\mathrm{CH}_{4}^{+}$ions $\left(k=2.5 \times 10^{-9} \mathrm{~cm}^{3}\right.$ $\left.s^{-1}\right)$ [54].

\section{K.E. ${ }_{c m}$ Determinations}

Rate constants for the reaction of $\mathrm{Ar}^{+}$with $\mathrm{N}_{2}$ were detcrmined from the first-order exponential decay of the $m / z 40$ ion signal as a function of time. A normal- 
ized $m / z 40$ ion signal was not used in these determinations as the $\mathrm{N}_{2}^{+}$product ions were ejected during the reaction time. To correct the $\mathrm{Ar}^{+}$ion signal for trapping losses or losses due to side reactions, the decay of the $m / z$ io jon signal was first determined when the mass-selected $\mathrm{Ar}^{+}$ions were allowed to react with the $\mathrm{N}_{2}$ at a given total pressure of $A r$ and $\mathrm{N}_{2}$ for a given reaction time. The decay of the $m / z 40$ ion signal was then determined at the same total pressure for the same reaction time with only Ar gas in the trap. This second decay was subtracted from the first for the calculation of $k$. This approach assumes that the loss of $\mathrm{Ar}^{+}$due to inefficient trapping or side reactions is more a function of the total pressure in the trap than the composition of the background gases.

The range of ionizing electron energies produced in the ITMS is sufficient to form both the $\mathrm{Ar}^{+}\left({ }^{2} \mathrm{P}_{3 / 2}\right)$ and $\mathrm{Ar}^{+}\left({ }^{2} \mathbf{P}_{1 / 2}\right)$ electronic states. Previous studies [46] have shown that the thermal rate constant for the reaction of $\mathrm{Ar}^{+}\left({ }^{2} \mathbf{P}_{1 / 2}\right)$ with $\mathrm{N}_{2}$ is three times greater than for $\mathrm{Ar}^{+}$ $\left({ }^{2} \mathrm{P}_{3 / 2}\right)$. However, the collisional quenching of $\mathrm{Ar}^{+}$ $\left({ }^{2} \mathbf{P}_{1,2}\right)$ by $\mathrm{Ar}, \mathrm{N}_{2}$, and He competes with the charge exchange reaction 1 . Because a range of background gas compositions was employed in this study, evidence of the excited $\mathrm{Ar}^{\prime} \quad\left({ }^{2} \mathrm{P}_{1 / 2}\right)$ state was sought in significant deviations of the $m / z 40$ ion signal from a first-order exponential fit at short reaction times [50]. No evidence of excited $\mathrm{Ar}^{+}\left({ }^{2} \mathrm{P}_{1 / 2}\right)$ was found in any of the studies involving $\mathrm{He}$ buffer gas. However, in some studies at low total pressures $\left(1-2 \times 10^{-6}\right.$ torr $)$ slight deviations of the $m / z 40$ signal from a first order fit were seen in the first 5-15 ms. Refitting of the data, having excluded the points obtained within the first $5-15 \mathrm{~ms}$, resulted in no significant changes in the rate constant and assigned K.E. ${ }_{\mathrm{cm}}$ values; that is, the refitted results fell within the reported experimental error.

K.E. values for the reaction of $\mathrm{Ar}^{+}$with $\mathrm{N}_{2}$ were assigned using the $k$ versus K.E. $\mathrm{cm}$ curve obtained in the flow drift studies reported in [45] and presented in Figure 2. This curve had been obtained at $298 \mathrm{~K}$ with He buffer gas. In a recent variable temperature-selected ion flow drift study, Viggiano et al. [47] report that $k$ for the reaction of $\mathrm{Ar}^{+}$with $\mathrm{N}_{2}$ varies as a function of the neutral gas temperature for a given K.E. ${ }_{\mathrm{cm}}$ over the range $0.05-0.20 \mathrm{eV}$. This increase in reactivity is at tributed to an increase in the rotational temperature of the $\mathrm{N}_{2}$ molecules. Therefore, they present changes in $k$ as a function of average total energy $(\mathrm{eV})$, where the average total energy is equal to the $K . E_{\mathrm{cm}}$ plus the average rotational energy for $\mathrm{N}_{2}$ at a given temperature $(=\mathrm{kT})$. In the present analysis of the ion energies in a QITMS, the K.E. $\mathrm{cm}$ values were assigned based on flow drift experiments performed at $298 \mathrm{~K}$, which corresponds to $0.026 \mathrm{eV}$ of $\mathrm{N}_{2}$ rotational energy. At the temperature of the ion trap in our experiments $(373 \mathrm{~K})$, $\mathrm{N}_{2}$ has $0.032 \mathrm{eV}$ of rotational energy. Thus, to correct for any possible rotational energy contribution from $\mathrm{N}_{2}$, the difference between the rotational temperatures,

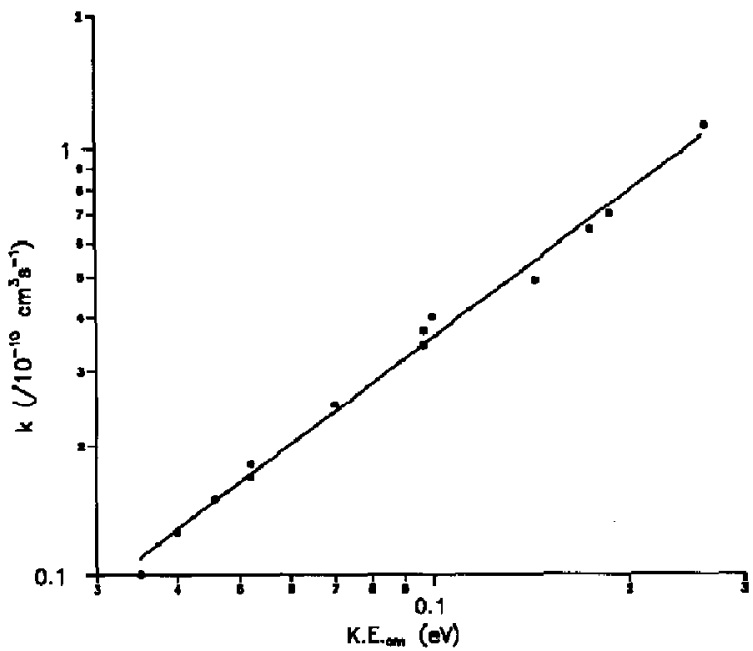

Figure 2. $k$ versus K.E. for the reaction $\mathrm{Ar}^{+}+\mathrm{N}_{2} \rightarrow \mathrm{N}_{2}^{+}+\mathrm{Ar}$ as reported in ref 45 . The first 13 data points from Figure 3 in ref 45 have been replotted here.

$0.006 \mathrm{eV}$, was subtracted from the $\mathrm{K}_{\mathrm{E}} \mathrm{E}_{\mathrm{cm}}$ values assigned from [45].

The rate constant for the reaction of $\mathrm{O}_{2}^{+}$with $\mathrm{CH}_{4}$ was calculated from the first-order exponential decay of the normalized $m / z 32$ ion signal as a function of time. The $m / z 32$ signal was normalized with respect to the ions at $m / z 19,29,32,33$, and $47 . K^{2} ._{.} \mathrm{cm}$ values were assigned based on the flow drift studies in $\mathrm{He}$ buffer gas at $298 \mathrm{~K}$ presented in ref 55 , consistent with the approach taken for the reaction of $\mathrm{Ar}^{+}$with $\mathrm{N}_{2}$. No attempt was made to correlate the branching ratios of the endothermic ion-molecule reaction product ions with the K.E. ${ }_{\text {crn }}$ for this reaction as any endothermic product ions were of $<2 \%$ relative intensity over the range of reaction times studied.

\section{Calculation of Experimental Error}

Errors in the K.E. ${ }_{\mathrm{cm}}$ values are expressed as the $95 \%$ confidence limits of the mean for at least three determinations, according to Shoemaker et al. [56]. Experimental values with no accompanying reported error are the results of a single $k$ determination. The estimated precision of the assigned $K . E_{\mathrm{cm}}$ values is $\pm 30 \%$.

\section{Results and Discussion}

$$
\mathrm{CH}_{4}^{+}+\mathrm{CH}_{4} \rightarrow \mathrm{CH}_{5}^{+}+\mathrm{CH}_{3} \text { Calibration Reaction }
$$

Typical plots of ion intensity versus time for the reaction of $\mathrm{CH}_{4}^{+}$with $\mathrm{CH}_{4}$ without and with $\mathrm{He}$ buffer gas are presented in Figure $3 a$ and $b$. In addition to the calibration reaction of interest (reaction 2), possible reactions leading to the products observed following 

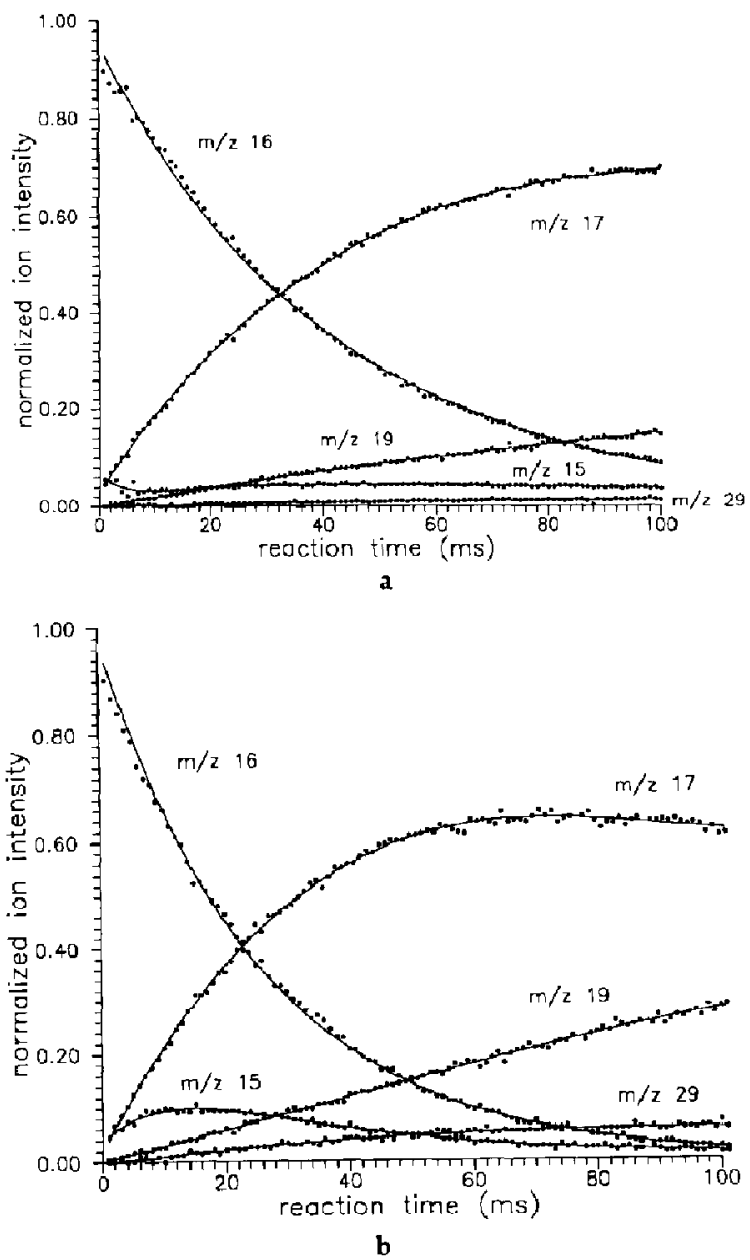

Figure 3. Ion intensity versus reaction time for the calibration reaction, $\mathrm{CH}_{4}^{+}+\mathrm{CH}_{4} \rightarrow \mathrm{CH}_{5}^{+}+\mathrm{CH}_{3}$. Methane at $1.0 \%$ $10^{-\mathrm{t}}$ torr; $\mathrm{q}_{2}\left(\mathrm{CH}_{4}^{\prime}\right)=0.732 ; \mathrm{m} / \mathrm{z} 16$ ion signal shown with a first-order exponential fit. (a) No $\mathrm{He}$ buffer gas; (b) with $\mathrm{He}$ buffer gas added to $1.0 \times 10^{-4}$ torr.

mass-selection of the $m / z 16$ ion include

$$
\begin{aligned}
\mathrm{CH}_{4}^{+}+\mathrm{H}_{2} \mathrm{O} & \rightarrow \mathrm{H}_{3} \mathrm{O}^{+}+\mathrm{CH}_{3} \\
\mathrm{CH}_{4}^{+}+\mathrm{M} & \rightarrow \mathrm{CH}_{3}^{+}+\mathrm{H}+\mathrm{M} \\
\mathrm{CH}_{5}^{+}+\mathrm{H}_{2} \mathrm{O} & \rightarrow \mathrm{H}_{3} \mathrm{O}^{+}+\mathrm{CH}_{4} \\
\mathrm{CH}_{5}^{+}+\mathrm{M} & \rightarrow \mathrm{CH}_{3}^{+}+\mathrm{H}_{2}+\mathrm{M} \\
\mathrm{CH}_{3}^{+}+\mathrm{CH}_{4} & \rightarrow \mathrm{C}_{2} \mathrm{H}_{5}^{+}+\mathrm{H}_{2}
\end{aligned}
$$

where, $\mathrm{M}=\mathrm{CH}_{4}$ or $\mathrm{He}$. The decrease in $m / z 16$ in Figure $3 a$ and $\mathbf{b}$ from reactions other than 2 can be attributed to proton transfer with background water (reaction 3) and collision-induced dissociation (CID) with either $\mathrm{CH}_{4}$ or $\mathrm{He}$ (reaction 4). Reaction 3 has a thermal rate constant of $k=2.5 \times 10^{-9} \mathrm{~cm}^{3} \mathrm{~s}^{-1}$ [54]; thus, it can be considered to be a significant side reaction at reaction times where the relative intensity of $m / z 16$ is greater than that of $m / z 17$. As $m / z 17$ increases, reaction 5 will begin to compete with reaction 3. Without He buffer gas (Figure 3a) the relative intensity of $m / z 15$ is seen to be slightly greater than 0.05 at reaction times $<10 \mathrm{~ms}$. This may be due to CID of $m / z 16$ with $\mathrm{CH}_{4}$ (reaction 4). Upon addition of He buffer gas (Figure $3 b$ ), $m / z 15$ is seen to increase in intensity from 0 to $15 \mathrm{~ms}$ and then decrease with an accompanying increase in the $m / z 29$ ion intensity. This is likely due to an increase in the rate of the CID reactions with $\mathrm{He}$ buffer (reaction 4 ) and (reaction 6 ), followed by the formation of $m / z 29$ ions via reaction 7 at reaction times $>15 \mathrm{~ms}$.

Rate constants for the calibration reaction at a variety of methane pressures with no He buffer present in the trap are presented in Table 1 . All $k$ values were obtained at a $\mathrm{q}_{2}\left(\mathrm{CH}_{4}^{+}\right)=0.732$ with no He buffer in the trap. The higher $k$ values at lower methane pressures are due to an increase in $\mathrm{CH}_{4}^{+}$loss due to reaction 3 , as the relative amount of background water (base pressure $\approx 4 \times 10^{-8}$ torr) is greater at lower methane pressures. An average $k=1.03 \pm 0.02 \times 10^{-9}$ $\mathrm{cm}^{3} \mathrm{~s}^{-1}$ is found at methane pressures above $2.2 \times$ $10^{-6}$ torr. This value agrees with the published value, $k_{i i t}=1.14 \times 10^{\circ} \mathrm{cm}^{3} \mathrm{~s}^{1}[54]$, indicating that no pressure differentials are present between the ion gauge and the ion trap reaction volume [50]. Thus, ion gauge readings corrected only for neutral species sensitivities can be used for the calculation of reaction rate constants. Further, the average value is in good agreement with those reported by Bonner et al. [6] $(k=1.1 \pm 0.4$ $\left.\times 10^{-9} \mathrm{~cm}^{3} \mathrm{~s}^{-1}\right)$, Lawson et al. [7] $(k=1.1 \pm 0.1 \times$ $\left.10^{-9} \mathrm{~cm}^{3} \mathrm{~s}^{-1}\right)$ and McLuckey et al. [57] $(k=1.5 \pm 0.5$ $\times 10^{9} \mathrm{~cm}^{3} \mathrm{~s}^{-1}$ ).

Table 1. Rate constants for the calibration reaction of $\mathrm{CH}_{4}^{+}$ with $\mathrm{CH}_{4}$ with no He buffer in the trap

\begin{tabular}{ccc}
$\begin{array}{c}\mathrm{CH}_{4} \text { pressure } \\
\left./ 10^{-7} \text { torr }\right)\end{array}$ & $\begin{array}{c}\text { Total } \\
\text { reaction time } \\
\text { (ms) }\end{array}$ & $\begin{array}{c}k^{a} \\
1.8\end{array}$ \\
\hline 2.6 & 240 & $\left.1.30^{-9} \mathrm{~cm}^{3} \mathrm{~s}^{-1}\right)$ \\
3.6 & 240 & 1.30 \\
4.3 & 240 & 1.30 \\
4.9 & 240 & 1.32 \\
5.8 & 240 & 1.25 \\
7.2 & 250 & $1.185 \pm 0.029$ \\
8.3 & 240 & 1.18 \\
9.5 & 240 & 1.16 \\
12 & 150 & 1.16 \\
22 & 100 & $1.128 \pm 0.042$ \\
29 & 100 & $1.04 \pm 0.16$ \\
34 & 60 & 1.04 \\
40 & 50 & $1.01 \pm 0.13$ \\
50 & 40 & 1.04 \\
& 25 & 1.01
\end{tabular}

${ }^{a}$ All $k$ values determined with $a_{2}\left(C / I_{4}^{+}\right)=0.732$ during the reection time. 
Rate constants for the calibration reaction at a variety of He buffer gas pressures are presented in Table 2 . A somewhat higher average $k=1.40 \pm 0.09$ is found with He buffer present in the trap. This is attributed to an increased loss of $m / z \quad 16$ via reaction 3 as an increase in background water is seen in full-scan mode upon addition of buffer even with cryocooling of the He line. The somewhat lower $k$ values found at high $\mathrm{He}$ pressures are due to scattering losses of the $\mathrm{CH}_{4}^{+}$ ions evident at these high pressures.

\section{K.E..$_{c m i}$ Dependent Ar ${ }^{+}+\mathrm{N}_{2} \rightarrow \mathrm{N}_{2}^{+}+$Ar Reaction}

Typical plots of ion intensity versus time for the reaction of $\mathrm{Ar}^{+}$with $\mathrm{N}_{2}$ without and with He buffer gas are presented in Figure $4 a$ and $b$. Figure $4 a$ and $b$ presents the product ions formed when $\mathrm{Ar}^{+}$reacts with $\mathrm{N}_{2}$ and were not used to determine $k$ for this reaction as the $\mathrm{N}_{2}^{+}$product ions have not been ejected. Upon ejection of $\mathrm{N}_{2}^{+}$only ions of $m / z 18$ and $m / z 40$ are seen. In addition to the charge exchange thermometer reaction of interest (reaction 1), possible reactions leading to the principal ions observed in Figure $4 a$ and $b$ include

$$
\begin{aligned}
\mathrm{Ar}^{+}+\mathrm{H}_{2} \mathrm{O} & \rightarrow \mathrm{H}_{2} \mathrm{O}^{+}+\mathrm{Ar} \\
\mathrm{Ar}^{+}+\mathrm{Ar} & \rightarrow \mathrm{Ar}^{+}+\mathrm{Ar} \\
\mathrm{N}_{2}^{+}+\mathrm{Ar} & \rightarrow \mathrm{Ar}^{+}+\mathrm{N}_{2} \\
\mathrm{~N}_{2}^{+}+\mathrm{H}_{2} \mathrm{O} & \rightarrow \mathrm{H}_{2} \mathrm{O}^{+}+\mathrm{N}_{2} \\
& \rightarrow \mathrm{HN}_{2}^{+}+\mathrm{OH}
\end{aligned}
$$

The thermal rate constant for reaction 8 is $1.54 \times$ $10^{-4} \mathrm{~cm}^{3} \mathrm{~s}^{-1}$ [54], and as such reaction 8 is a significant side reaction on the time scale of these experiments. However, the subtraction procedure used for the calculation of $k$ should correct for any loss of $\mathrm{Ar}^{+}$ due to reaction with background $\mathrm{H}_{2} \mathrm{O}$. The symmetric

Table 2. Rate constants for calibration reaction of $\mathrm{CH}_{4}^{+}$ with $\mathrm{CH}_{4}$ with $\mathrm{He}$ buffer in the trap

\begin{tabular}{cccc}
$\begin{array}{c}\mathrm{CH}_{4} \text { pressure pressure with He reaction time } \\
\left(/ 10^{-7} \text { torr }\right)\end{array}$ & $\begin{array}{c}\text { Total } \\
(\mathrm{ms})\end{array}$ & $\left(/ 10^{-5}{ }^{-9} \mathrm{~cm}^{3} \mathrm{~s}^{-1}\right)$ \\
\hline \hline 12 & 2.6 & 100 & $1.32 \pm 0.09$ \\
12 & 5.4 & 100 & $1.43 \pm 0.19$ \\
12 & 10 & 100 & $1.41 \pm 0.14$ \\
12 & 25 & 100 & $1.61 \pm 0.25$ \\
12 & 51 & 100 & $1.56 \pm 0.18$ \\
35 & 5.5 & 50 & 1.41 \\
35 & 10 & 30 & 1.34 \\
50 & 5.5 & 30 & 1.28 \\
50 & 10 & 30 & 1.27 \\
& & Average & $1.40 \pm 0.09$ \\
\hline
\end{tabular}

${ }^{a}$ All $k$ values determined with $q_{z}\left(\mathrm{CH}_{4}^{+}\right)=0.732$ during the reaction time.
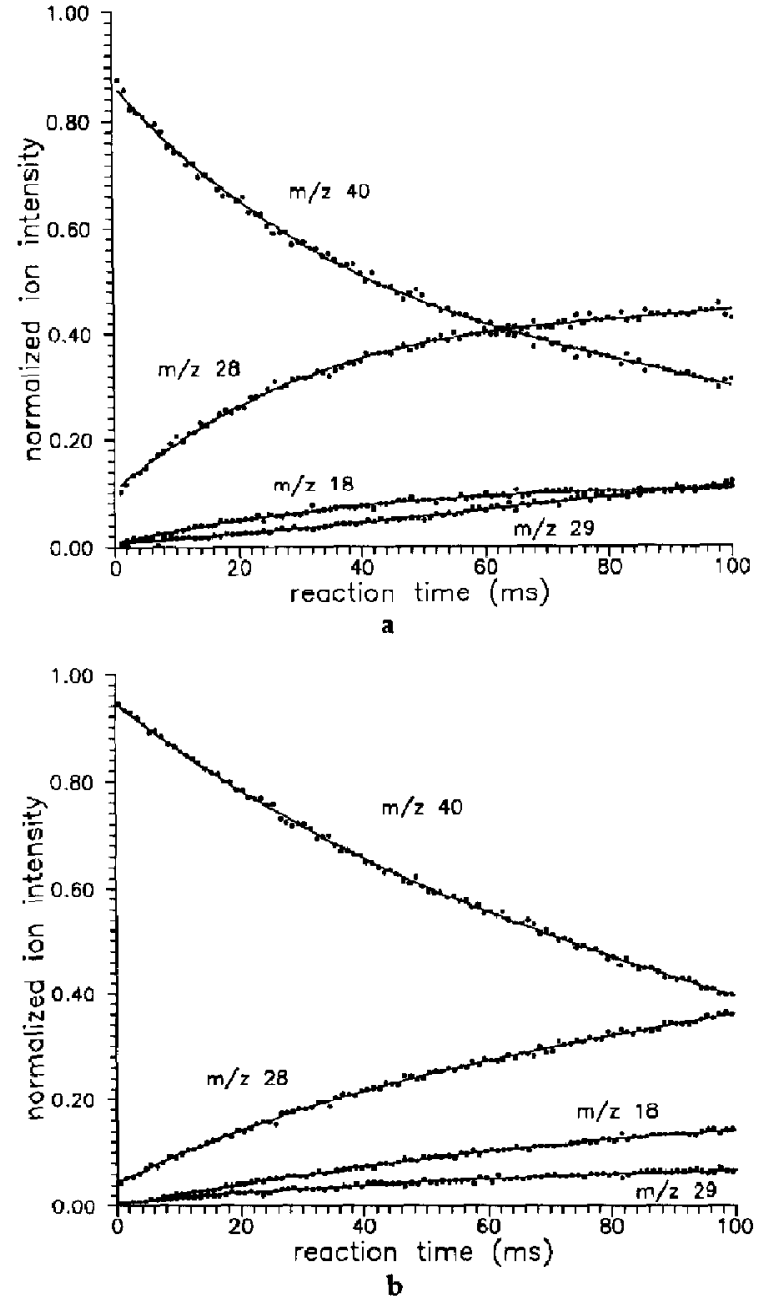

Figure 4. Ion intensity versus reaction time for the reaction of $\mathrm{Ar}^{+}$with $\mathrm{N}_{2}$ without $\mathrm{N}_{2}^{+}$ejection. $1: 1 \mathrm{Ar}: \mathrm{N}_{2}$ at $1.0 \times 10^{-5}$ torr; $\mathrm{q}_{\mathrm{z}}\left(\mathrm{Ar}^{+}\right)=0.295$. (a) No He buffer gas; (b) with He buffer gas added to $1.0 \times 10^{-4}$ turr.

charge exchange reaction (reaction 9) simply serves to thermalize the $\mathrm{Ar}^{+}$ions. Reactions 10-12 need not be considered in the rate constant determinations upon ejection of $\mathrm{N}_{2}^{+}$.

Rate constants and assigned kinetic energies, $K . E_{{ }_{c m}}$, for the reaction of $\mathrm{Ar}^{+}$and $\mathrm{N}_{2}$ with no He buffer gas are presented in Table 3 . The large errors associated with the K.E..$_{-\mathrm{m}}$ values at the lowest pressure $(13.5 \times$ $10^{-7}$ torr) are due to the fact that one of the triplicate determinations of the rate constant was a factor of two smaller than the other two for both $\mathrm{q}_{z}\left(\mathrm{Ar}^{+}\right)$values. Performance of the statistical " $Q$ " test did not allow rejection of these points due to the small number of determinations considered. The errors in these points are thus anomalously high in comparison to the remaining results in Table 3 .

Several trends in the data presented in Table 3 are noteworthy. First, while the K.E. $\mathrm{sm}_{\mathrm{cm}}$ for the two $\mathrm{q}_{z}\left(\mathrm{Ar}^{+}\right)$ 
Table 3. Rate constants, $k$, and K.E. ${ }_{\mathrm{cm}}$ for the reaction of $\mathrm{Ar}^{+}$with $\mathrm{N}_{2}$ with no He buffer gas

\begin{tabular}{|c|c|c|c|c|c|c|}
\hline \multirow{2}{*}{$\begin{array}{l}\text { Total pressure } \\
\left(/ 10^{7} \text { torr }\right)^{*}\end{array}$} & \multirow{2}{*}{$\begin{array}{c}\mathrm{Ar}: \mathrm{N}_{2} \\
\text { pressure }\end{array}$} & \multirow{2}{*}{$\begin{array}{c}\text { Total } \\
\text { reaction time } \\
\text { (ms) }\end{array}$} & \multicolumn{2}{|c|}{$\mathrm{q}_{\mathrm{L}}\left(\mathrm{Ar^{ \prime }}\right)=0.295$} & \multicolumn{2}{|c|}{$\mathrm{q}_{2}\left(\mathrm{~A}_{\mathrm{T}}{ }^{-1}\right)=0.454$} \\
\hline & & & $k\left(/ 10^{-11} \mathrm{~cm}^{3} \mathrm{~s}^{-1}\right)$ & $K . E_{-c m}(e V)^{a}$ & $k\left(/ 10^{-11} \mathrm{~cm}^{3} \mathrm{~s}^{-1}\right)$ & K.E. ${ }_{\mathrm{cm}}(\mathrm{eV})^{\mathrm{a}}$ \\
\hline 13.5 & $10: 4$ & 200 & $11 \pm 12$ & $0.26 \pm 0.28$ & $12 \pm 12$ & $0.26 \pm 0.27$ \\
\hline 14.7 & $3: 10$ & 100 & $5.6 \pm 2.9$ & $0.14 \pm 0.07$ & $9.5 \pm 4.1$ & $0.23 \pm 0.10$ \\
\hline 17.4 & $10: 7$ & 200 & $7.5 \pm 5.3$ & $0.19 \pm 0.12$ & $11.3 \pm 7.8$ & $0.27 \pm 0.19$ \\
\hline 16.7 & $4: 10$ & 100 & $5.6 \pm 4.3$ & $0.14 \pm 0.10$ & $9.5 \pm 1.8$ & $0,23 \pm 0,04$ \\
\hline 22.3 & $8: 10$ & 200 & $7.2 \pm 2.5$ & $0.18 \pm 0.06$ & $9.8 \pm 5.6$ & $0.24 \pm 0.13$ \\
\hline 22.0 & $9: 10$ & 200 & $5.6 \pm 2.6$ & $0.14 \pm 0.06$ & $8.41 \pm 0.56$ & $0.21 \pm 0.01$ \\
\hline 63.0 & $10: 2$ & 200 & $5.3 \pm 1.7$ & $0.13 \pm 0.04$ & $6.8 \pm 2.2$ & $0.17 \pm 0.05$ \\
\hline 61.7 & 2:10 & 100 & $5.0 \pm 1.1$ & $0.13 \pm 0.03$ & $6.6 \pm 1.8$ & $0.16 \pm 0.04$ \\
\hline 110 & $10: 1$ & 200 & $5.8 \pm 2.2$ & $0.15 \pm 0.10$ & $6.6 \pm 1.1$ & $0.16 \pm 0.03$ \\
\hline \multirow[t]{2}{*}{123} & $1: 10$ & 80 & $4.2 \pm 1.4$ & $0.11 \pm 0.03$ & $5.3 \pm 1.2$ & $0.13 \pm 0.03$ \\
\hline & & Average & $6.3 \pm 1.6$ & $0.16 \pm 0.04$ & $7.6 \pm 1.5$ & $0.21 \pm 0.03$ \\
\hline
\end{tabular}

${ }^{3}$ K.E. ${ }_{\mathrm{cm}}$ values assigned from Figure 2 [45] and corrected for the rotational temperature of $\mathrm{N}_{2}[47]$.

values agree within experimental error ${ }_{r}$ a lower average K.E.cm is seen at the lower $\mathrm{q}_{z}\left(\mathrm{Ar}^{+}\right)=0.295$, as anticipated at this lower $\mathrm{rf}$ amplitude. Second, the lower overall K.E. $\mathrm{cm}$ values and higher precision found for $k$ determinations performed with a higher relative pressures of $\mathrm{N}_{2}$ likely reflect the higher buffering efficiency anticipated when a greater proportion of the lower molecular weight $\mathrm{N}_{2}$ is present in the trap [18]. It may, however, also be due to a bias in the subtraction procedure used to determine the $m / z 40$ ion signal decay when $\mathrm{N}_{2}$ is the principal component of the background gas as opposed to Ar. Finally, a greater decrease in $K . E_{\mathrm{cm}}$ is seen with increasing pressure at a $\mathrm{q}_{2}\left(\mathrm{Ar}^{+}\right)=0.454$, indicating that buffering of the ions by the background gases plays a greater role at higher $\mathrm{q}_{e}\left(\mathrm{Ar}^{+}\right)$values.

Rate constants and assigned K.E. ${ }_{\mathrm{cm}}$ values for the reaction of $\mathrm{Ar}^{+}$with $\mathrm{N}_{2}$ at a variety of $\mathrm{He}$ buffer gas pressures are presented in Table 4 . The $\mathrm{He}$ range studied spans the typical operating pressure of $1.0 \times$
$10^{-4}$ torr (uncorrected ion gauge reading). It can be seen that at a $\mathrm{q}_{z}\left(\mathrm{Ar}^{+}\right)=0.295$ and an $\mathrm{Ar}$ and $\mathrm{N}_{2}$ pressure of $1.0 \times 10^{-5}$ torr, no significant decrease in ion energy is seen when He buffer gas is added to the trap. A somewhat more marked decrease is seen at a $\mathrm{q}_{z}\left(\mathrm{Ar}^{+}\right)=0.454$. These relatively small decreases in $K$. . $_{\mathrm{cm}}$ indicate that the $\mathrm{Ar}$ and $\mathrm{N}_{2}$ can provide a significant degree of buffering. The trend toward lower energies at higher $\mathrm{He}$ pressures is attributed to the increase in scattering losses of $\mathrm{Ar}^{+}$ions witnessed at these higher pressures. Thus, for the experimental con ditions presented in Table 4, increasing the He buffer gas pressure above the standard operating pressure of $1.0 \times 10^{-4}$ torr provides no additional cooling effect. A similar observation of the effect of increasing the He buffer gas pressure is reported by Schaaf et al. [35]. Further, the average K.E.cm values over the He range studied for both $\mathrm{q}_{z}\left(\mathrm{Ar}^{+}\right)=0.295$ and 0.454 are found to be approximately equal; this indicates that for an $\mathrm{Ar}$ and $\mathrm{N}_{2}$ pressure of $1.0 \times 10^{-5}$ torr, any effect of

Table 4. Rate constants, $k$, and K.E. for the reaction of $\mathrm{Ar}^{+}$with $\mathrm{N}_{2}$ at a variety of $\mathrm{He}$ buffer gas pressures

\begin{tabular}{|c|c|c|c|c|}
\hline \multirow{2}{*}{$\begin{array}{c}\text { Total pressure with } \mathrm{He} \\
\left(/ 10^{-5} \text { torr) }\right.\end{array}$} & \multicolumn{2}{|c|}{$a_{z}\left(A^{+}\right)=0.295$} & \multicolumn{2}{|c|}{$\mathrm{a}_{2}\left(\mathrm{~A}_{\mathrm{r}}{ }^{\prime}\right)=0.454$} \\
\hline & $k\left(/ 10^{-11} \mathrm{~cm}^{3} \mathrm{~s}^{-1}\right)$ & $K, E_{-\mathrm{cm}}(\mathrm{gV})^{\mathrm{a}}$ & $k\left(/ 10^{11} \mathrm{~cm}^{3} \mathrm{~s}^{-1}\right)$ & K.E. ${ }_{\mathrm{cm}}(\mathrm{eV})^{\mathrm{a}}$ \\
\hline $\mathrm{No} \overline{\mathrm{He}}$ & $5.4 \pm 1.5$ & $0.14 \pm 0.04$ & $6.4 \pm 2.4$ & $0.16 \pm 0.06$ \\
\hline 2.6 & $5.5 \pm 0.89$ & $0.14 \pm 0.02$ & $5.82 \pm 0.20$ & $0.15 \pm 0.01$ \\
\hline 5.1 & $5.4 \pm 1.4$ & $0.14 \pm 0.03$ & $5.2 \pm 1.7$ & $0.13 \pm 0.04$ \\
\hline 10.0 & $5.5 \pm 2.6$ & $0.14 \pm 0.06$ & $5.1 \pm 2.3$ & $0.13 \pm 0.05$ \\
\hline 25.0 & $5.0 \pm 0.7$ & $0.13 \pm 0.02$ & $5.3 \pm 1.5$ & $0.13 \pm 0.04$ \\
\hline 51.0 & $4.8 \pm 1.0$ & $0.12 \pm 0.03$ & $4.4 \pm 1.3$ & $0.11 \pm 0.03$ \\
\hline Average with $\mathrm{He}$ & $5.2 \pm 0.4$ & $0.13 \pm 0.01$ & $5.2 \pm 0.7$ & $0.13 \pm 0.02$ \\
\hline
\end{tabular}

${ }^{a}$ All K.E.em values assigned from Figure 2 [45] and corrected for the rotational temperature of $\mathrm{N}_{2}$ [47] All values are for a $1: 1 \mathrm{Ar} ; \mathrm{N}_{2}$ pressure ratio al a cotal pressure of $1.0 \times 10^{-5}$ torr prior to addition of He buffer and a $100 \mathrm{~ms}$ reaction time. 
$\mathrm{q}_{z}\left(\mathrm{Ar}^{+}\right)$on the K.E. ${ }_{\mathrm{cm}}$ is masked by the collisional cooling of the Ar, $\mathrm{N}_{2}$, and He.

A thorough examination of the effect of $\mathrm{q}_{z}\left(\mathrm{Ar}^{+}\right)$ on the K.E $\mathrm{E}_{\mathrm{cm}}$ is presented in Figure $5 \mathrm{a}$ and $\mathrm{b}$. In Figure 5a, the $q_{z}\left(\mathrm{Ar}^{+}\right)$for a 1:1 ratio of $\mathrm{Ar}: \mathrm{N}_{2}$ at a total pressure of $1.0 \times 10^{-5}$ torr was varied both without and with He buffer gas present in the trap. The same study was repeated in Figure $5 b$ with an Ar and $\mathrm{N}_{2}$ pressure of $2.2 \times 10^{-6}$ torr. In all cases, a decrease in the average $K . E_{. c m}$ is seen upon addition of $\mathrm{He}$ buffer gas as is a trend toward higher $K . E ._{\mathrm{cm}}$ with increasing $\mathrm{q}_{\mathrm{z}}\left(\mathrm{Ar}^{+}\right)$. These trends are much more marked for a lower total pressure of $\mathrm{Ar}$ and $\mathrm{N}_{2}$ (Figure $5 b)$. Thus, the amplitude of the $\mathrm{rf}$ applied to the ring during the reaction time has a greater effect on the K.E. ${ }_{\mathrm{cm}}$ for lower partial pressures of $\mathrm{Ar}$ and $\mathrm{N}$, where the buffering ability of these neutrals is less effective.
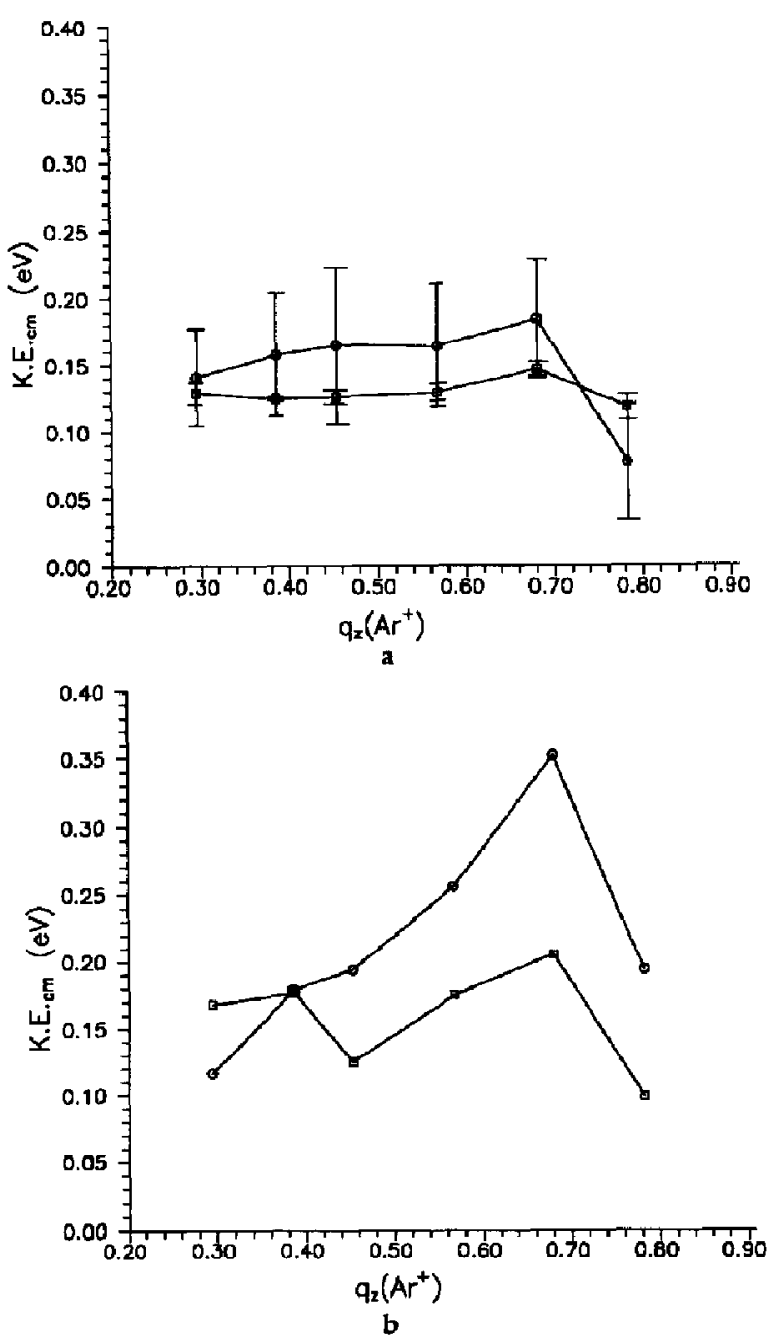

Figure 5. K.E. $\mathrm{cm}$ versus $\mathrm{q}_{x}\left(\mathrm{Ar}^{+}\right)$as determined from $k$ for the reaction $\mathrm{Ar}^{+}+\mathrm{N}_{2} \rightarrow \mathrm{N}_{2}^{+}+\mathrm{Ar}$. All points for a 100 ms reaction time. (a) (O) $1: 1 \mathrm{Ar}: \mathrm{N}_{2}$ at $1.0 \times 10^{-5}$ torr; ( $\square$ ) He buffer gas added to $1.0 \times 10^{-4}$ torr; (b) (O) $1: 1 \mathrm{Ar}: \mathrm{N}_{2}$ at $2.2 \times 10^{-6}$ torr; (a) He buffer gas added to $1.0 \times 10^{-4}$ torr.
The increase in precision of the rate constant determinations with $\mathrm{He}$ in Figure $5 \mathrm{a}$ is attributed to an increase in the ion extraction efficiency as ions are buffered toward the center of the trap [52]. The crossover in K.E. ${ }_{\mathrm{cm}}$ in the first two points in Figure $5 \mathrm{~b}$ falls within the $30 \%$ accuracy associated with single $k$ determinations. Further experiments are required to determine if this crossover is reproducible.

It is interesting to note the apparent decrease in K.E. ${ }_{\mathrm{cm}}$ in Figure $5 \mathrm{a}$ and $\mathrm{b}$ at $\mathrm{a} \mathrm{q}_{z}\left(\mathrm{Ar}^{+}\right)=0.783$. This $\mathrm{q}_{\mathrm{x}}\left(\mathrm{Ar}^{+}\right)$corresponds to the position under the upper apex of the stability diagram. At this point, the trapping efficiency of the $\mathrm{Ar}^{+}$ions decreases, particularly with no He buffer gas [15]. Thus, the decays of the $m / z 40$ ion signal determined at high $\mathrm{q}_{z}\left(\mathrm{Ar}^{+}\right)$reflect the loss of $\mathrm{Ar}^{+}$due to decreased trapping efficiencies to a greater extent than $\mathrm{Ar}^{+}$losses due to reaction with $\mathrm{N}_{2}$. This leads to artificially low K.E. ${ }_{\mathrm{cm}}$ values, and as such, the methad of $k$ determination employed in this study breaks down at high $\mathrm{q}_{z}\left(\mathrm{Ar}^{+}\right)$values.

The 95\% confidence limits presented in this study indicate that it is difficult to assign absolute $K . E . \mathrm{cm}$ values under any set of experimental conditions, particularly when no He buffer is present in the trap. However, the average ion energies obtained with the $\mathrm{Ar}^{+} / \mathrm{N}_{2}$ chemical thermometer reaction reflect anticipated trends in ion energy and lead to $K . E_{. c m}$ values in the range $0.11-0.34 \mathrm{eV}$. These energies are a factor of 10 lower than those reported by Lawson et al. [7] and correspond to $\approx 4 \% e \mathrm{D}_{\mathrm{z}}$ with no He buffer and $\approx 2 \%$ $\mathrm{eD}_{2}$ with He buffer present in the trap. (The average $e D_{2}$ values were calculated for $\mathrm{q}_{2}$ values of less than 0.454 by using $V_{0-p}$ rf amplitudes [25].)

\section{"Effective" Ion Temperatures}

Use of the term "temperature" to describe the ions stored in a QITMS was first introduced by Dehmelt $[18,19]$ and extended by Blatt et al. [58]. In this description, the ions possess Gaussian spatial and velocity distributions; an equilibrium temperature arises from a balancing of the rf heating effects with those of the collisional cooling mechanisms active in the trap. Experimental measures of the ion density distribution were first presented by Knight and Prior [34]. In these measures, profiles of ${ }^{6} \mathrm{Li}^{+}$ions trapped for $1 \mathrm{~s}$ at $10^{-9}$ torr with no $\mathrm{He}$ buffer were observed with a laser scanning method. The profiles were found to be consistent with a Gaussian distribution and observed values for the radius of the ion cloud lead to ion temperatures of $\approx 5000 \mathrm{~K}$. Implied Maxwell-Boltzmann distributions of stored ion energies have since been used in numerous ion temperature determinations $[10,31,32$, $36,39,40]$. In the present study, the $\mathrm{Ar}^{+}$ions suffer $\approx 7$ collisions $\mathrm{ms}^{-1}$ when He buffer is present at $1.0 \times 10^{-4}$ torr (uncorrected ion gauge reading) [59]. These momentum-loss collisions should serve to balance any heating effects due to the rf field. As such, 
ion temperatures can be determined assuming a Maxwell-Boltzmarn distribution of ion energies.

We propose a definition of "effective" temperature for He buffered $\mathrm{Ar}^{+}$ions based on the assigned $\mathrm{K} . \mathrm{E} . \mathrm{cm}$ values arising from the charge exchange reaction (reaction 1) where

$$
\mathrm{K} . \mathrm{E}_{\mathrm{cm}}=1 / 2 \mu v_{\mathrm{rel}}^{2}(\mathrm{eV})
$$

and where $\mu$ equals the reduced mass $(\mathrm{kg})$ and $v_{\text {rel }}$ equals the relative velocity of the ion-molecule pair $\left(\mathrm{ms}^{-1}\right.$ ) [60]. Assuming a Maxwell-Boltzmann distribution of energy for both the ion and the neutral species,

$$
K . E_{c^{\prime} \mathrm{m}}=\frac{3 k}{2}\left(\frac{m_{i} m_{n}}{m_{i}+m_{n}}\right)\left[\frac{T_{i}}{m_{i}}+\frac{T_{n}}{m_{n}}\right](e V)
$$

Thus,

$$
T_{i}=\left[\frac{2}{3 k} \frac{\left(m_{i}+m_{n}\right)}{\left(m_{i} m_{n}\right)} K \cdot E_{c_{c m}}-\frac{T_{n}}{m_{n}}\right] m_{1}(K)
$$

where, $m_{i}$ and $m_{n}$ are the masses of the $A r^{+}$ion and $N_{2}$ neutral species $(\mathrm{kg})$, respectively, $T_{n}$ is the neutral gas temperature $(K)$, and $T_{i}$ is the effective ion temperature $(\mathrm{K})$. In the case of He buffered ground state $\mathrm{Ar}^{+}$ ions for which the K.E. ${ }_{\mathrm{cm}}$ values have been corrected for rotational contributions from $\mathrm{N}_{2}, \mathrm{~T}_{\mathrm{i}}$ corresponds to an effective kinetic temperature of the trapped $\mathrm{Ar}^{+}$ ions.

Effective kinetic temperatures for the He buffered $\mathrm{Ar}^{+}$ions arising from the $K . \mathrm{E}_{\mathrm{cm}}$ values presented in Table 4 are: $1930 \pm 170 \mathrm{~K}$ for $\mathrm{q}_{z}\left(\mathrm{Ar}^{+}\right)=0.295$ and $1890 \pm 320$ for $\mathrm{q}_{2}\left(\mathrm{Ar}^{+}\right)=0.454$; those for the variable $\mathrm{q}_{2}\left(\mathrm{Ar}^{+}\right)$studies (Figure $5 \mathrm{a}$ and $\mathrm{b}$ ) range from $1700 \pm 25$ $\mathrm{K}$ (for $\mathrm{Ar}$ and $\mathrm{N}_{2}$ at $1.0 \times 10^{-5}$ torr, and $\mathrm{a} \mathrm{q}_{6}\left(\mathrm{Ar}^{+}\right)=$ 0.386 ) to $3300 \mathrm{~K}$ (for $\mathrm{Ar}$ and $\mathrm{N}_{2}$ at $2.2 \times 10^{-6}$ torr, and a $\left.\mathrm{q}_{z}\left(\mathrm{Ar}^{+}\right)=0.681\right)$. Thus, the effective ion temperatures are within the range $\approx 1700-3300 \mathrm{~K}$.

\section{K.E.cm Dependent $\mathrm{O}_{2}^{+}+\mathrm{CH}_{4} \rightarrow \mathrm{CH}_{3} \mathrm{O}_{2}^{+}+\mathrm{H}$} Reaction

All studies of the reaction of $\mathrm{O}_{2}^{+}$with $\mathrm{CH}_{4}$ were performed at a $\mathrm{q}_{z}\left(\mathrm{O}_{2}^{1}\right)=0.369$ with $1.0 \times 10^{-5}$ torr pressure of $\mathrm{O}_{2}$ and $\mathrm{CH}_{4}(1: 1$ ratio) and a $500 \mathrm{~ms}$ reaction time. The principal product ion is observed at $m / 247$ both with and without $\mathrm{He}$ buffer; minor products at $m / z 29(\approx 2 \%$ relative intensity) and $m / z 19$ ( $<1 \%$ relative intensity) are also seen over the reaction time. The $m / z 47$ and 29 product ions can be attributed to the exothermic and endothermic reaction pathways, respectively $[42,61]$,

$$
\begin{aligned}
& \mathrm{O}_{2}^{+}+\mathrm{CH}_{4} \stackrel{k}{\rightarrow} \mathrm{CH}_{3} \mathrm{O}_{2}^{+}+\mathrm{H} \\
& \mathrm{O}_{2}^{\prime}+\mathrm{CH}_{4} \rightarrow \mathrm{CH}_{3}^{\prime}+\mathrm{IO}_{2}
\end{aligned}
$$

where reaction 13 is exothermic by $1 \mathrm{eV}$, and where the $m / z 15$ products from the endothermic reaction 14 $(-0.24 \mathrm{eV})$ react with excess methane to form the ion at $m / z 29$. No products arising from the second possible endnthermic channel $(-0.60 \mathrm{eV})$

$$
\mathrm{O}_{2}^{+}+\mathrm{CH}_{4} \rightarrow \mathrm{CH}_{4}^{+}+\mathrm{O}_{2}
$$

were seen in any of the kinetic studies. The $m / z 19$ ions may arise from either [61],

$$
\mathrm{O}_{2}^{+}+\mathrm{CH}_{4} \rightarrow \mathrm{H}_{3} \mathrm{O}^{+}+\mathrm{HCO}
$$

or,

$$
\mathrm{CH}_{3} \mathrm{O}_{2}^{+}+\mathrm{H}_{2} \mathrm{O} \rightarrow \mathrm{H}_{3} \mathrm{O}^{+}+\mathrm{CH}_{2} \mathrm{O}_{2}
$$

It is interesting to note that in our studies with $\mathrm{He}$ buffer, an anomalous ion signal at $m / z 33$ began to appear at a $250 \mathrm{~ms}$ reaction time and increased to $\approx 15 \%$ by $500 \mathrm{~ms}$. The appearance of this ion distorted the first-order exponential decay of the $m / z 32$ ion signal at reaction times greater than $250 \mathrm{~ms}$. This distortion, coupled with the fact that there is no accompanying decrease in the $m / z 47$ ion signal, indicated that the $m / z 33$ ion signal was arising directly from the $\mathrm{O}_{2}^{+}$ions and not from a possible consecutive reaction. Upon closer examination of the $\mathrm{m} / \mathrm{z} 32$ peak profile, it was found that the peak became skewed toward higher mass at reaction times greater than 250 ms. Thus, the $m / z 33$ ion signal arose from an error in the centroiding of the $m / z 32$ peak by the ITMS data system. It is assumed that this distortion is due to the onset of space charge at these long reaction times as no distortion of the peak profile is seen in any of the studies with no He buffer. Thus, in calculating the rate constant for reaction 13 in the studies with He buffer, the intensity of the $m / z 33$ was added to that of the $m / z 32$ over the $500 \mathrm{~ms}$ reaction time. This resulted in an anticipated first-order exponential decay with no distortions.

A rate constant, $k=8.6 \pm 0.5 \times 10^{-12} \mathrm{~cm}^{3} \mathrm{~s}^{-1}$ was found for the reaction of $\mathrm{O}_{2}^{+}$with $\mathrm{CH}_{4}$ with no $\mathrm{He}$ buffer gas present in the trap; $k=6.26 \pm 0.09 \times$ $10^{12} \mathrm{~cm}^{3} \mathrm{~s}^{1}$ was found with $1.0 \times 10^{-4}$ torr of $\mathrm{He}$ present in the trap. Based on these rate constants,

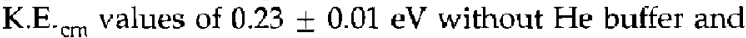
$0.17 \pm 0.01 \mathrm{eV}$ with $\mathrm{He}$ buffer are assigned [55]. These values are somewhat higher than those obtained from the $\mathrm{Ar}^{+} / \mathrm{N}_{2}$ thermometer reaction under similar conditions (second points, Figure 5a). However, they do fall within the range $0.11-0.34 \mathrm{eV}$.

The rate constants presented here are of the same order of magnitude as those obtained by Nourse and Kenttämaa [10]. However, they report an increase in $k$ for the reaction of $\mathrm{O}_{2}^{+}$with $\mathrm{CH}_{4}$ in the presence of $\mathrm{He}$ buffer $\left(6.6 \times 10^{-12} \mathrm{~cm}^{3} \mathrm{~s}^{-1} \pm 20 \%\right.$ without He buffer gas versus $8.2 \times 10^{-12} \mathrm{~cm}^{3} \mathrm{~s}^{-1} \pm 20 \%$ in the presence of 1 mtorr of $\mathrm{He}$ ). By using the present method of ion energy assignment, these rate constants correspond to an incrcase in ion energy from K.E. $\mathrm{cm}=0.18 \mathrm{eV}$ to 
K.E. ${ }_{\mathrm{cm}}=0.22 \mathrm{eV}$ upon addition of $\mathrm{He}$ buffer. The decay of the $m / z 32$ signal over a $1.6 \mathrm{~s}$ reaction time in the presence of $\mathrm{He}$ buffer presented by Nourse and Kenttämaa (Figure 2 in ref 10 ) contains distortions from a first-order exponential fit at reaction times < $500 \mathrm{~ms}$. These distortions are similar to those witnessed in our analyses with He buffer when the growth of the signal at $m / z 33$ at reaction times greater than $250 \mathrm{~ms}$ had not been taken into account. Moreover, a first-order analysis of our distorted $m / z 32$ signals with and withoul He buffer gas leads to the same effect on the rate constants as that reported in ref 10 ; that is, a higher rate constant was obtained when $\mathrm{He}$ butter was present in the trap. Ihis suggests that the data reported in ref 10 may have suffered from the same centroiding problems due to the onset of space charge at long reaction times with He buffer, resulting in an apparent decrease in the rate constant with $\mathrm{He}$ buffer. Given the increase in the rate constant reported in ref 10 upon addition of $\mathrm{He}$ buffer, and the recent reanalysis [49] of the $k$ versus $T_{\text {eff }}$ curve presented by Adams ct al. [41], we suggest that the present method of ion energy assignment for the reaction of $\mathrm{O}_{2}^{+}$with $\mathrm{CH}_{4}$ is preferable to that presented by Nourse and Kenttämaa [10].

\section{Conclusions}

We have carried out a detailed study of the energies of the ions stored in a QITMS. K.E. $\mathrm{cm}$ values were assigned based on rate constants for the charge exchange reaction of $\mathrm{Ar}^{+}$with $\mathrm{N}_{2}$ by using previous flow drift data. While the sometimes large experimental error arising from the use of this chemical "thermometer" reaction makes assignment of absolute $K . E_{. \mathrm{cm}}$ under any set of experimental conditions difficult, certain trends in the $K . E_{{ }_{c m}}$ values are noteworthy: (1) There is a consistent decrease in $K . E_{.}{ }_{c m}$ upon addition of $\mathrm{He}$ buffer gas to the reaction system; however, increasing the He buffer pressure above $1.0 \times 10^{-4}$ torr (uncorrected ion gauge reading) appears to have little additional cooling effect. (2) An increase in K.E. ${ }_{\mathrm{cm}}$ is seen with increasing $\mathrm{q}_{\mathrm{z}}\left(\mathrm{Ar}^{+}\right)$both with and without $\mathrm{He}$ buffer gas. This increase in energy is more marked at lower pressures of $\mathrm{Ar}$ and $\mathrm{N}_{2}$, presumably due to the decreased buffering abilities of these neutral gases at lower total pressures. The experimentally determined K.E. ${ }_{\mathrm{cm}}$ values arising from the reaction of $\mathrm{Ar}^{+}$with $\mathrm{N}_{2}$ under a variety of experimental conditions are found to all lie within the range $0.11-0.34 \mathrm{eV}$.

We also present a definition of "effective" ion temperature for He buffered $\mathrm{Ar}^{+}$ions based on the assigned K.E. $\mathrm{cm}$ and the assumption that the ions are described by a Maxwell-Boltzmann distribution of kinetic energies. The resulting ion temperatures lie within the range $\approx 1700-3300 \mathrm{~K}$.

We have reexamined the use of the reaction of $\mathrm{O}_{2}^{+}$ with $\mathrm{CH}_{4}$ as a chemical thermometer for probing ion energies in a QITMS. We have used a method of assigning K.E.cm values based on previous flow drift studies consistent with the approach taken for the $\mathrm{Ar}^{+} / \mathrm{N}_{2}$ reaction. The $K . E_{\text {.cm }}$ values arising from the $\mathrm{O}_{2}^{+} / \mathrm{CH}_{4}$ reaction are: $0.23 \pm 0.01 \mathrm{eV}$ with no He buffer in the trap, and $0.17 \pm 0.01 \mathrm{eV}$ with $\mathrm{He}$ buffer. These are within the range of $K . ._{\mathrm{cm}}$ values arising from the reaction of $\mathrm{Ar}^{+}$with $\mathrm{N}_{2}$. We suggest that the effective ion energies reported here for the $\mathrm{O}_{2}^{+}$ions are a more accurate indication of the ion temperatures than that of $600-700 \mathrm{~K}$ reported previously [10].

\section{Acknowledgments}

Special thanks are extended to J. E. Bruce for many helpful discussions regarding this work, to N. A. Yates and M. S. Freund for their data acquisition and reduction programs, and to J. V. Johnson for the frequency optimization program. We also thank H. I. Kenttämaa, A. A. Viggiano, and R. B. Moore for copies of their manuscripts prior to publication. AmTech project 88-01, funded by NASA and Finnigan MAT, is gralefully acknowledged for partial funding of this work.

\section{References}

1. Nourse, B. D.; Conks, R. G. Anal. Chim. Acta 1990, 228, 1-21

2. Louris, I. N.; Brodbelt-Lustig, J. S.; Cooks, R. G.; Glish, G. L.; Van Berkel, G. J.; McLuckey, S. A. Int. I, Mass Spectrom. Ion Proc. 1990, 96, 117-137.

3. Todd, J. F. J. Mass Spectrom. Rev. 1991, 10, 3-52.

4. McLuckey, S. A.; Glish, G. L.; Van Berkel, G. J. Int. J. Mass Spectrom. Ion Proc. 1991, 106, 213-235.

5. Berberich, D. W.; Hail, M. E.; Johnson, J. V.; Yost, R. A. Int. J. Mass Spectrom. Ion Proc. 1989, 94, 115-147.

6. Bonner, R. F.: Lawson, G.; Todd, J. F. J. Int. J. Mass. Spectrom. Ion Phys. 1972 / 73, 10, 197-203.

7. Lawson, G.; Boruner, R. F.; Mathers, R. E.; Todd, J. F. J.; March, R. E. J. Chem. Soc., Faraday Trarts. I 1976, 72, 545-557.

8. Fulford, J. E.; Dupuis, J. W.; March, R. E. Can. I. Chem. 1978 $56,2324-2330$.

9. Armitage, M. A.; Fulford, J. E.; Duong N.-H; Hughes, R. J.; March, R. E. Can J. Chem. 1979, 57, 2108-2113.

10. Nourse, B. D.; Kenttämaa, H. I, I. Phys. Chem, 1990, 94, $5809-5812$

11. DeBrau, G. B.; Fulford, J. F.; I ewars, F. G.; March, R. F. Int. J. Mass. Spectrom. lon Phys. 1978, 26, 345-351

12. Armitage, M. A.; Higgins, M. J.; Lewars, E. G.; March, R. E I. Am. Chem. Soc. 1980, 102, 5064-5068.

13. Kamar, A.; Young, A. B.; March, R. E. Can J. Chem. 1986, 64, 2368-2370.

14. Nourse, B. D.; Cooks, R. G. Int. I. Mass Spectrom. Ion Proc. 1991, 106, 249-272.

15. Brodbelt-Lustig, J. S.; Cooks, R. G. Talanta 1989, 36, 255-260.

16. Einhorn, J.; Kenttämaa, H. I.; Cooks, R. G. J. Am. Soc. Mass Spectrom. 1991, 2, 305-313.

17. Kiremire, B.; Traldi, P.; Guiotto, A.; Pastorini, G.; Chilin, A.; Vettori, U. Int. J. Mass. Spectrom. Ion Proc. 1991, 106, 283-298.

18. Delumeit, H. G. Adv. At. Mol. Phys. 1967, 3, 53-72.

19. Major, F. G.; Dehmelt, H. G. Phys. Rez. 1968, 170, 91-107.

20. Bonner, R. F,; March, R, E. Int. J. Mass Spectrom. Ion Phys. $1977,25,411-431$.

21. Lawson, G.; Todd, J. F. J.; Bonner, R. F. In Dynamic Mass Spectrometry; Heyden: London, 1976.

22. Dawson, P. H. Int. I. Mass Spectrom. Ion Phys. 1977, 24. 447-451. 
23. Todd, J. F. J.; Freer, D. A.; Waldren, R. M. Int. I. Mass Spectront. Ion Pliys. 1980, 35, 185-203.

24. Todd, J. F. J.: Waldren, R. M.; Bonner, R. F. Int. I. Mass Spectrom. Ion Pliys. 1980, 34, 17 36, and references therein.

25. March, R. E.; Hughes, R. J. Quadrupole Storage Mass Spectrometry and Its Applications; John Wiley: New York, 1989, chapters 2 and 3.

26. André, J.; Vedel, F. J. de Phys. 1977, 38, 1381-1398.

27. Vedel, F.; André, J.; Vedel, M.; Brincourt, G. Phys. Reou. A 1983, 27, 2321-2330.

28. Vedel, F.; André, J. Phys. Rev. A 1984, 29, 2098-2101.

29. Vedel, F.; André, J. Int. J. Mass Spectront. Lon Proc. 1985, 65. $1-22$.

30. Vedel, F. Int. I. Mass Spectron. Ion Proc. 1991, 106, 3-61

31. Church, D. A.; Dehmelt, H. G. I. Appl. Phys, 1969, 40, 3421-3424.

32. Church, D. A. Phys. Rev. A 1988, 37, 277- 279.

33. Iffländer, R.; Werth, G. Metrologia 1977, 13, 167-170,

34. Knight, R. D.; Prior, M. H. I. Appl. Pinys. 1979, 50, 3044-3049.

35. Schaaf, $\mathrm{H}_{. ;}$Schmeling, U.; Werth, G. Appl. Phys. 1981, 25. $249-251$

36. Cutler, L. S.; Giffard, R. P.; McGuire, M. D. Appt. Pltys, B $1985,36,137-142$.

37. Cutler, L. S.r Flory, C. A.; Giffard, R. P.; McGuire, M. D Appl. Plys. B 1986, 39, 251-259.

38. Münch, A.; Berkler, M.; Gerz, Ch.; Wilstorf, D.; Werth, G. Plys. Rev. A 1987, 35,4147-4150.

39. Siemers, I.; Blatt, R.; Sauter. Th,; Neuhauser, W. Plyys. Rev. A $1988,38,5121 \cdot 5128$.

40. Lunney, M. D. N.; Buchinger, F.; Moore, R. B. I. Mod. Optics, $1992,39,349-360$.

41. Adams, N. G.; Smith, D.; Ferguson, E. E. Int. J. Mass Spectrom. Ion Proc: 1985, 67, 67-74.

42. Durup-Ferguson, M.; Bohringer, H.; Fahey, D. W.; Fehsenteld, F. C.; Ferguson, E. E. T. Chem. Phys. 1984, 81, 2657-2666.

43. Lindinger, W.; Howorka, F.; Lukac, P.; Kuhn, S.; Villinger, 11.; Alge, E.; Ramler, H. Phys. Ren. A 1981, 23, 2319-2326.
44. Smith, D: Adams, N. G. Phys. Rev. A 1981, 23, 2327-2330.

45. Dotan, I.; Lindinger, W. I. Chem. Phys. 1982, 76, 4972-4977.

46. Hamdan, M.; Birkinshaw, K.; Twiddy, N. D. Int. J. Mass Spectrom. Ion Proc. 1984, 57, 225-231.

47. Viggiano, A. A.; Van Doren, J. M.; Morris, R. A.; Paulson, J F. J. Chem. Phys. 1990, 93, 4761-4765, and references therein

48. Bartmess, J. E. In Structure, Reactivity, and Thermochemisiry of lons; D. Reidel: Holland, 1987.

19. Viggiano, A. A.; Mortis, R. A.; Van Doren, ]. M.; Paulson, J F. J. Chem. Phys 1992, 96, 275-284.

50. Bruce, J. E.; Eyler, J. R. J. Am. Soc. Mass Spectrom. 1992, $727-733$.

51. Pedder, R, E.; Yost, R. A. Procedings of the 36th ASMS Conference on Mass Spectrometry and Allied Topics; San Francisco, CA, 1988.

52. Stafford, G. C.: Kelley, P. E.; Syka, J. E. P.; Reynolds, W. E. Todd, J. F. J. Int. J. Mass Spectrom. Ion Pitys. 1984, 60, 85-98.

53. Henctuman, M. J. In Ion-Molecule Reactions, Plenum Press: New York, 1972.

54. Ikezoe, Y;: Matsuoka, S; Takebe, $M$,; Viggiano, A. A. Gas Phase lon-Molectile Reaction Rate Constants Through 1986; Maruzen Company: Tokyo, 1987.

55. Dotan, I,; Fehsenfeld, F. C.; Albritton, D. L. 1. Chem. Phys. 1978, 68, 5665-5666.

56. Shoemaker, D. P; Garland, C. W.; Steinfeld, J. L; Nibler, ]. W. Experincents in Plusical Chemistry; MoGraw-Hill: New York, 1981.

57. Mrluckey, S A; Gilish, G. 1.; Asann, K G.; Van Berkel, C. J Anal. Chem. 1988, 60, 2312-2314.

58. Blatt, R.; Zoller, P, Holzmüller, G.; Siemers, I. Z. Phys. D 1986, 4, 121-126.

59. Gioumousis, G; Stevenson, D. P. I. Chem. Phys, 1958, 29. 294-249.

60. Kennard, E. H. Kinetic Theory of Gases with an Introduction to Statistical Mechanics; McGraw-Hill: New York, 1938.

61. Van Doran, J. M.; Barlow, 5. E.; DePuy, C. H.; Bierbaum, V. M.: Dotan, I.; Ferguson, E. E. J. Phys. Chem. 1986, 90. $2772-2777$ 